\title{
A simple and fast sampling method for assessing chemical and nutritional characteristics of pumpkins
}

\author{
Bruno T Cardoso' $\mathbb{D}$; Semíramis RR Ramos ${ }^{2} \mathbb{D}$; Ricardo E Alves ${ }^{2} \mathbb{D} ;$ Carlos Alberto da S Ledo $^{3} \mathbb{D}$; Antonina \\ dos Santos ${ }^{1} \mathbb{D}$; Hister Maria M dos Santos ${ }^{1} \mathbb{D}$
}

\begin{abstract}
'Embrapa Tabuleiros Costeiros, Aracaju-SE, Brasil; bruno.cardoso@embrapa.br; antoninadossantos@yahoo.com.br; hister.matias@hotmail. com; ${ }^{2}$ Embrapa Alimentos e Territórios, Maceió-AL, Brasil; semiramis.ramos@embrapa.br; ricardo.alves@embrapa.br; ${ }^{3}$ Embrapa Mandioca e Fruticultura, Cruz das Almas-BA, Brasil; carlos.ledo@embrapa.br
\end{abstract}

\begin{abstract}
In the chemical and nutritional analyses of pumpkin, the size of bulk sample recommended by the method of reference, makes the process time consuming and difficult to execute. The purpose of the present study was to evaluate different sampling methods to indicate the most suitable one to replace reference method to determine the levels of total carotenoids, total soluble solids, and moisture in pumpkin. A completely randomized design was used with four treatments and 18 replications. The proposed methods consisted basically in changing the way of taking bulk samples from the fruits: cylinders method, quartile method, and the slice method. Samples obtained by proposed methods were analyzed for moisture content, total carotenoids and total soluble solids. Results obtained by each proposed method were compared against the method of reference. Cylinders method showed the best results and was the easiest to be carried out, consuming only about $1 / 10$ of the time required in relation to the method of reference. The cylinder method was rapid, efficient, reliable and exhibited the greatest suitability for replacing the reference method.
\end{abstract}

Keywords: Cucurbita moschata, food analysis, carotenoid, sampling procedure, quartering.

\section{RESUMO}

Um método rápido e simples de amostragem para estimar características químicas e nutricionais em abóboras

Nas análises químicas e nutricionais da abóbora, o tamanho da amostra bruta recomendada pelo método de referência (dois quartis opostos), torna o processo demorado e difícil de executar. O objetivo do presente estudo foi avaliar diferentes métodos de amostragem para indicar o mais apropriado para substituir o método de referência na determinação de carotenóides totais, sólidos solúveis totais e umidade em abóbora. Utilizou-se o delineamento inteiramente causalizado com quatro tratamentos e 18 repetições. Os métodos propostos, denominados método dos cilindros, método do quartil e método da fatia, consistiram na mudança da amostra bruta a ser coletada nos frutos. As amostras obtidas por meio dos métodos propostos foram analisadas para os teores de umidade, carotenóides totais e sólidos solúveis totais. Os resultados obtidos pela aplicação de cada método proposto foram comparados com os resultados obtidos por meio da aplicação do método de referência. O método dos cilindros exibiu os melhores resultados e foi o mais fácil de ser executado, consumindo apenas $1 / 10$ do tempo requerido pelo método de referência, sendo por essa razão, indicado como o mais rapido, eficiente e confiável para substituir o método de referência.

Palavras-chave: Cucurbita moschata, análise de alimentos, carotenoide, procedimento de amostragem, quarteamento.

\section{Received on September 13, 2019; accepted on June 9, 2020}

$\mathrm{T}$ he analytical methods used for the identification and quantification of carotenoids have been improved and refined over time (Rodriguez-Amaya, 2000). However, analytic inaccuracies have been detected, mainly related to the existence of discrepant data on the levels of these compounds reported for the same vegetable (Provesi \& Amante, 2015). Among the main factors of quality loss in the results generated by the analyses of carotenoids, it is possible to highlight incomplete extraction; inefficient chromatographic separation; errors in the identification of peaks, quantifications, and calculations; samples are not representative of the lots under investigation; physical losses; isomerization and oxidation of carotenoids during analyses or during storage of samples (RodriguezAmaya \& Kimura, 2004). These factors are distributed among all analysis steps, since sampling to quantification (Rodriguez-Amaya, 2000).

Sampling is the first step in the analysis of carotenoids content. Typically, it encompasses a sequence of steps, from obtaining a bulk sample, collection of increment in different parts of the lots to be analysed, to reduce the amount of the bulk sample in order to generate a sub-sample and, finally, reduction of particle size of the subsample to obtain an analytical sample (Vogel, 2000). The latter is also known as laboratory sample, from which aliquots are collected for individual determinations (Harris, 2010). 
The importance of sampling for the accuracy of the results is equivalent to any other step of the analysis. The variance of the analytical procedure, as a whole, is equivalent to the sum of accumulated errors in each step (Harris, 2010; Miller \& Miller, 2010). On the other hand, in terms of the accuracy of the process, it is known that the most effective way to approach the analytical results to the values considered to be the most accurate is improving the reliability of the step with greatest variance, which normally corresponds to the sampling step (Morawicki, 2010). Studies based on analyses of foods have shown increased attention devoted to sampling, unlike studies on carotenoids, which have not devoted enough attention to that step (Rodriguez-Amaya, 2001). Most of the scientific articles have not mentioned the sampling procedures used, and some have done it in a superficial manner (Condurso et al., 2012; Carvalho et al., 2014; Jaswir et al., 2014; Chan-Léon et al., 2017). In addition, specialized literature has few studies focused on the preparation of sampling methods for the quantification of carotenoid content in a particular plant. Normally, they include generic recommendations to analyse different analytes in plant groups with similar agronomic characteristics.

For pumpkin, the proposed sampling method is that recommended for large fruits and vegetables. It consists of longitudinal quartering of the fruit; random collection of two opposing quarters; peel removal; and homogenization of the quarters in food processors (Carvalho et al., 2012). This method determines how the bulk sample (the two opposite quarters collected) should be obtained from the lot (whole fruit). It also determines how to reduce particle size (ground in food processor). However, it does not inform how the bulk sample should be reduced to obtain the laboratory sample. For fruits weighing from 1.9 to $7.2 \mathrm{~kg}$, as those mentioned by Ramos et al. (2010) the bulk sample would weigh between 0.95 and $3.6 \mathrm{~kg}$, whereas the weight of aliquots used for individual determinations would range from 2 to $15 \mathrm{~g}$. This fact makes it clear that there is a need of a procedure for bulk sample reduction, or that the collection of fruit increments to obtain the bulk sample is changed so that the reduction becomes unnecessary. Saini et al. (2015) mention the reduction of sample volume as an important point to consider in sample preparation.

The use of the method currently recommended for the sampling of pumpkin requires time due to the weight and size of the fruit. It favors the occurrence of oxidative degradation and isomerization of carotenoids resulting from long exposure to oxygen, and enzymes and acids released from the cells after cutting the fruits (RodriguezAmaya, 2002). It also makes the removal of the thin and rigid peel of the pumpkin difficult, poses a risk of accidents to teams working in the processing due to the use of knives for long periods in low-light environments. The processing of samples under low light conditions is a requirement of the methodology for the analysis of carotenoids due to the photosensitivity of carotenoids (Luterotti et al., 2013). It is necessary to obtain a method equivalent to the traditional one in terms of representativeness of the fruit. This new method should be able to minimize the problems caused by the reference method.

This study was carried out to evaluate different sampling methods in order to indicate the most suitable one to replace reference method to determine the levels of total carotenoids, total soluble solids, and moisture content in pumpkin (Cucurbita moschata)

\section{MATERIAL AND METHODS}

\section{Plant material}

Pumpkin landraces fruits with globular, flattened and cordiform shapes were harvested in the Agricultural Experiment Station "Pedro Arle" (Frei Paulo, Sergipe State) and were transported to Embrapa Tabuleiros Costeiros (CPATC), Aracaju, Sergipe State, Brazil. Those fruits were cleaned with water and stored under room refrigeration at $18^{\circ} \mathrm{C}$.

Eighteen healthy, ripe and non- injured fruits were evaluated. The analyses were carried out from December, 2015 to March, 2016 in the Post-Harvest Laboratory, at CPATC. A completely randomized experimental design was used containing four treatments (sampling methods) and 18 replications.

\section{Sampling methods}

The proposed methods (PMs) were prepared considering that the distribution of constituents throughout the equatorial axis of pumpkins is homogeneous, and the assumption that the longitudinal direction exhibits the greatest variation, as noted in the edible parts of other vegetables. In addition, it was established that the PMs should take into account all the thickness of the fruit pulp, avoiding the need of having to assess this effect. Before collecting the samples, the fruits had the four longitudinal quarters (Q1; Q2; Q3; and Q4) delimited to the latitudinal direction by four lines, called: L1; L2; L3; and L4. Q1 was defined by L1 and L2, Q2 by L2 and L3, and so on. After the delimitation of the quarters, additional marks were done in order to guide sample collection when using the other PMs evaluated.

\section{Cylinder method}

Arbitrarily, it was defined that bulk samples would be composed of cylindrical portions collected around the fruits using a core sampler (coconut opener tool). Cylinders were collected using a collecting strategy based on quarters. To perform the collection of cylinders in a quarter, that portion of the fruit was longitudinally divided into three slices (F1Q1, F2Q1, F3Q1) having the same height (one third of the distance between the peduncle and the flower scar) and being laterally delimited by the same lines that delimited the quarters (Figure 1).

For a better representation of the fruit, the ratio between the mass of the cylinders collected in each slice (CMSn) was determined to coincide with the ratio between the mass of each slice (MSn), i.e

CMS1:CMS2:CM3 = MS1:MS2:MS3

\section{(Equation 1)}

After the delimitation of the slices, 
the quarters were cut in order to separate the slices to be weighed and obtain the MS1:MS2:MS3 ratio. The collection of different numbers of cylinders in each slice was tested until the sum of the mass of the cylinders collected in each slice was in accordance with equation 1. For purposes of convenience, it was determined that the tests of number of cylinders would begin with one cylinder taken from the lowest-mass slice. After these tests, the cylinder method was established as described below:

-To draw on the fruit, straight lines perpendicular to each other, starting in the peduncle and ending in the flower scar;

-To draw on the fruit three divisions with equal length on each line; one division near the peduncle, one division in the center, and one division near the flower scar;

-To collect five cylinders from each line; one near the peduncle, three from the central division of the lines, and one near the flower scar. The cylinders from the upper and lower divisions should be positioned approximately in the middle of each division and the cylinders of the central part would be approximately positioned in an equidistant manner;

-The collection of cylinders should be performed using a core sampler (coconut opener tool) of approximately $1 \mathrm{~cm}$ in diameter and whose length was greater than the thickness of the fruit (pulp plus peel);

-To remove the peel and the mucilage from the cylinders using a knife;

-To cut the cylinders into smaller portions (about $1 \mathrm{~cm}$ high) and grind using a domestic food processor.

\section{Quarter method (QM) and slice method (SM)}

These two sampling methods are similar and consist of using a whole quarter of the fruit (QM) and a longitudinal slice taken from one of the quarters (SM). It was established that the slice corresponding to the SM should have one-fourth of the quarter width. Prior to the collection, the slices were drawn on the peel of the fruits.

\section{Reference method (RM)}

The RM consisted of using two quarters located in a diametrically opposing position with respect to the fruits, as recommended by RodriguezAmaya et al. (2008).

\section{Physical analysis}

Before collecting the samples for applying the methods to be evaluated, the fruits were weighed and had their dimensions measured, i.e., diameter (D) and height (H) (Brasil, 2004).

\section{Sample preparation and chemical analyses}

The sampling methods were evaluated to obtain bulk samples from each fruit used for replications in the experiment. Subsequently, each bulk sample was processed. The processing of the raw sample was carried out according to the methodology of Carvalho et al. (2014). The peels and seeds were removed, the pulps were sliced to obtain 1-cm-edge cubes, or 1-cm high cylinders (for the CM), and the resulting sliced pulps were ground. Analytical samples for each sampling method were collected from the pulp ground. The analytical samples were defined as $100 \mathrm{~g}$. The order for obtaining the analytical samples and performing the chemical analyses was determined by drawing. For comparison purposes between the methods, times required to obtain the analytical sample in each method was recorded and measured in minutes. For determining the content of total soluble solids (TSS), five grams of ground pulps were pressed to obtain juice, which was filtered through cotton, and finally dripped on the prism of a digital refractometer (Atago PR-32 $\alpha$ [alpha] Pallete-Series). The results were expressed as percentage (grams of TSS/100 g of sample. The moisture content (MC), expressed in grams of water/100 $\mathrm{g}$ of fresh sample, was determined acoording to Bhat \& Bhat (2013), except for using two grams of sample instead of $30 \mathrm{~g}$, and drying the samples at $105^{\circ} \mathrm{C}$ instead of $130^{\circ} \mathrm{C}$. Total carotenoids (TCA) were determined after extracting these compounds with acetone, partition of the resulting extract into petroleum ether, and measurement of the extract absorbance in petroleum ether at 450 $\mathrm{nm}$, as described by Carvalho et al.
(2014).

\section{Classification of evaluated} methods

The results obtained by the methods under study were used to identify "the most suitable" method to replace the RM. The criteria used to classify the methods were 1) not differing statistically from the RM with regard to the chemical characteristics assessed; 2) less time required for processing; 3 ) easy to be performed.

\section{Statistical analysis}

Each of the eighteen fruits used in the experiment was regarded as repetition. The results of the physical characteristics assessed were described as mean, standard deviation (SD), and coefficient of variation $(\mathrm{CV})$ corresponding to each shape and, also, to all of them together, i.e., all the fruits of all shapes used in the experiment. The assessments of the chemical characteristics of each fruit and each evaluated method were performed in triplicate. The mean, the SD and the CV "between" and "inside" the fruits were calculated using the results obtained by the RM. The SD "inside" the fruit (SDI) was calculated using the equation (Barros Neto et al., 2001):

$$
\begin{aligned}
& \mathrm{SDI}=\left\{\left[(\mathrm{N} 1-1) \mathrm{SA}^{2}+(\mathrm{N} 2-1) \mathrm{SB}^{2}+\ldots\right.\right. \\
& \left.+(\mathrm{NN}-1) \mathrm{SN}^{2}\right] /[((\mathrm{N} 1-1)+(\mathrm{N} 2-1)+\ldots \\
& +(\mathrm{NN}-1)]\} 1 / 2(\text { Equation } 2)
\end{aligned}
$$

where $\mathrm{N} 1, \mathrm{~N} 2$, and $\mathrm{NN}$ correspond to the number of tests replicated for the quantification of a given characteristic in each fruit, from the first to the $\mathrm{n}^{\text {th }}$ fruit assessed; $\mathrm{SA}, \mathrm{SB}$, and $\mathrm{SN}$ correspond to the SD between replicate analyses of a given characteristic assessed in a given fruit. The CV "inside" the fruit expected for each chemical characteristic assessed was calculated using equation:

$$
\left[\mathrm{CV}(\%)=2^{(1-0.5 \log \mathrm{C})}\right]
$$

\section{(Equation 3)}

known as Horwitz equation or Horwitz trumpet (Sieber et al., 2019), where C is the constituent concentration.

The statistical comparison between the mean of each characteristic in each method evaluated and the characteristic corresponding to the RM was accomplished using the paired 
t-test. The comparisons that resulted in $\mathrm{p}<0.05$ were considered indicative of statistical difference between the PMs and the RM.

Time spent by each method to obtain the analytical sample was compared using analysis of variance (one-factor ANOVA). The Tukey test at 5\% probability was used to compare means of sampling methods. These statistical analyses were performed using the GraphPad Prism software (GraphPad Software, Inc., San Diego, USA).

\section{RESULTS AND DISCUSSION}

Mean values of $5.8 \mathrm{~kg}(\mathrm{CV}=37.0 \%)$, $25.0 \mathrm{~cm}(\mathrm{CV}=12.1 \%), 20.5 \mathrm{~cm}(\mathrm{CV}=$ $20.4 \%$ ) were identified for the weight, diameter and height of the fruit, respectively. For pulp thickness, the value was $3.4 \mathrm{~cm}(\mathrm{CV}=17.4 \%)$. The values obtained in the present study are slightly higher than those obtained for pumpkin progenies by Borges et al. (2019), who reported values between 2.3 and $4.2 \mathrm{~kg}$ for fruit weight and 1.6 to $3.2 \mathrm{~cm}$ for pulp thickness. The high variability in these characteristics was due to the phenotypic variability in pumpkin landraces; it made it possible to test the robustness of the methods evaluated checking their applicability in fruits with such different weight values and shapes. High phenotypic variability for fruit weight and pulp thickness has also been found in other studies with Cucurbita sp. landraces (Priori et al., 2018).

As the statistical analysis considered the fixed model the results presented in this study could only be related to the fruits within the dimensions and weight range assessed. At the same time, the method currently recommended (RM) does not derive from specific studies for the quantification of TCA, MC, and TSS in pumpkins, but consists of a generic recommendation for fruits of any species considered big in size, and weight (Rodriguez-Amaya et al., 2008).

The TCA, MC, and TSS values were measured using raw samples obtained by the RM. Those values ranged from 115.57 to $392.60 \mu \mathrm{g}$ of carotenoids/g of fresh matter, from 84.05 to $93.08 \mathrm{~g}$ of
$\mathrm{H}_{2} \mathrm{O} / 100 \mathrm{~g}$ of fresh matter, and from 6.5 to $14.9 \%$, respectively. This amplitude in the results, demonstrated that the variability in the results was only low for MC. This high variation resulted from genetic variability between the fruits used in the study. This variability represents a difficulty for the statistical comparison of methods because a given PM will only differ from the RM if the magnitude of the difference between the results obtained by its application, and the results obtained by the application of the $\mathrm{RM}$ is greater than the experimental error (Harris, 2010).

On the other hand, this variability allows the assessment of the robustness of the PMs, subjecting them to the comparison with the RM in a large range of chemical characteristics.

The levels of TCA, MC, and TSS found in the present study were like those reported previously (Carvalho et al., 2012), in which was observed $236 \mu \mathrm{g}$ of carotenoids/g fresh sample, $85.29 \mathrm{~g}$ of $\mathrm{H}_{2} \mathrm{O} / 100 \mathrm{~g}$ of fresh sample, and $12.1 \%$ of TSS. The use of equation 2 to calculate a joint estimation of the SD enabled us to assess the variability in one fruit, but with 32 degrees of freedom (Table 1). This deviation corresponded to the precision of the analytical procedure, considering all its stages, including the sampling step performed with the RM, and is independent of the variability between the fruits.

The CVs, calculated from the SDs, indicated an excellent experimental precision for the quantification of all chemical and nutritional characteristics assessed. The value of the $\mathrm{CV}$ was inversely proportional to the magnitude of the results. The lowest $\mathrm{CV}$ corresponded to the characteristic with the greatest magnitude (MC), and

Table 1. Estimate of intra-fruit variability exhibited by pumpkin varieties relating to chemical and nutritional characteristics. Aracaju, Embrapa, 2016.

\begin{tabular}{lcccc}
\hline $\begin{array}{l}\text { Evaluated } \\
\text { characteristic }\end{array}$ & Mean & SD & $\begin{array}{c}\text { Experimental } \\
\text { CV (\%) }\end{array}$ & $\begin{array}{c}\text { Predicted } \\
\text { CV (\%) }\end{array}$ \\
\hline TCA & 223.1 & 5.54 & 2.28 & 3.54 \\
MC & 89.2 & 0.21 & 0.29 & 1.02 \\
TSS & 10.4 & 0.17 & 1.29 & 1.40 \\
\hline
\end{tabular}

$\mathrm{TCA}=$ total carotenoids content $(\mathrm{g}$ of carotenoids $/ \mathrm{g}) ; \mathrm{MC}=$ moisture content $(\mathrm{g}$ of water $/ 100$ $\mathrm{g}) ; \mathrm{TSS}=$ total soluble solids $(\%) ; \mathrm{SD}=$ standard deviation of eighteen replicates. Experimental $\mathrm{CV}=$ coefficient of variation of all the fruits assessed in the experiment, and predicted; $\mathrm{CV}=$ coefficient of variation predicted by Horwitz curve.

Table 2. Total carotenoids content (TCA), moisture content (MC), and total soluble solids (TSS) of pumpkin samples collected with the methods proposed \{quartile method [QM] and slice method $[\mathrm{SM}]\}$ and the reference method (RM). Aracaju, Embrapa, 2019.

\begin{tabular}{lccccc}
\hline \multirow{2}{*}{ Statistics Characteristic } & \multicolumn{5}{c}{ Methods } \\
\cline { 3 - 6 } & $\begin{array}{c}\text { Reference } \\
\text { (RM) }\end{array}$ & $\begin{array}{c}\text { Cylinders } \\
\text { (CM) }\end{array}$ & $\begin{array}{c}\text { Quartile } \\
\text { (QM) }\end{array}$ & Slice (SM) \\
\hline Mean & TCA & 227.24 & 232.45 & 228.06 & 240.05 \\
\hline CI & & -14.3 to 3.9 & -13.5 to 11.9 & -25.0 to -0.6 \\
P & & 0.2252 & 0.8870 & 0.0414 \\
\hline Mean & MC & 88.64 & 88.61 & 88.66 & 88.21 \\
\hline CI & & & -0.34 to 0.36 & -0.35 to 0.29 & -0.10 to 0.94 \\
P & & & 0.9496 & 0.8350 & 0.1022 \\
\hline Mean & TSS & 10.91 & 10.93 & 10.80 & 11.14 \\
\hline CI & & & -0.43 to 0.43 & -0.12 to 0.38 & -0.61 to 0.15 \\
P & & & 1.0000 & 0.2740 & 0.1993 \\
\hline
\end{tabular}

$\mathrm{SD}=$ Standard deviation; $\mathrm{CV}=$ Coefficient of variation; $\mathrm{CI}=95 \%$ Confidence interval; $\mathrm{P}=$, Probability value. 


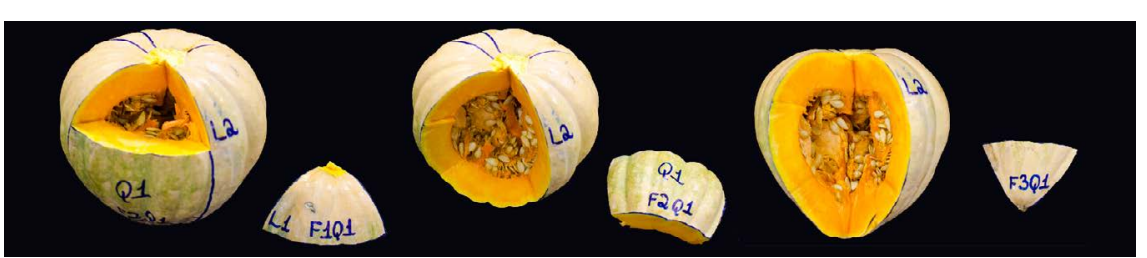

Figure 1. Slices used to determine the number and position of the cylinders to be collected in pumpkin fruit. Aracaju, Embrapa, 2016.

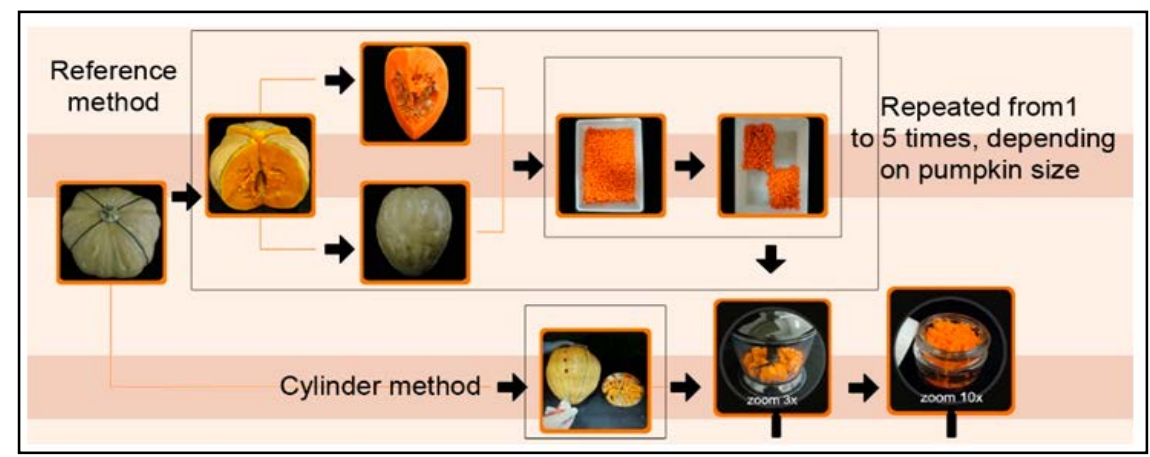

Figure 2. Scheme demonstrating the steps to obtain analytical samples using Reference and Cylinder methods. Aracaju, Embrapa, 2019.

Table 3. Average time for obtaining the analytical samples of pumpkin pulp and the weight of the bulk samples, using different sampling methods. Aracaju, Embrapa, 2019

\begin{tabular}{lcccc}
\hline Sampling method & Time (min) & CV (\%) & $\begin{array}{c}\text { Weight of bulk } \\
\text { sample (g) }\end{array}$ & CV (\%) \\
\hline Reference (RM) & $58.6 \mathrm{a}$ & 30.2 & 2906.0 & 35.49 \\
Quartile (QM) & $27.2 \mathrm{~b}$ & 34.3 & 1475.1 & 32.53 \\
Slice (SM) & $7,4 \mathrm{c}$ & 39.2 & 336.3 & 32.30 \\
Cylinder (MC) & $5.4 \mathrm{c}$ & 16.1 & 83.4 & 7.05 \\
\hline
\end{tabular}

Time values and Weight of bulk sample $=$ means of eighteen replicates; $\mathrm{CV}=$ coefficient of variation. Values in the same column with different superscript letters are significantly different (Tukey, $\mathrm{p}<0.05$ ).

the largest $\mathrm{CV}$ corresponded to the characteristic with the lowest magnitude (TCA).

The behaviors of the CVs based on magnitudes of the characteristics assessed were also provided by the Horwitz curve. This equation estimates the CV from the concentration of constituent and establishes that characteristics with greater concentrations tend to exhibit lower $\mathrm{CVs}$ in comparison to characteristics with lower concentrations (Speakman \& Shackley, 2013).

The values of CVs predicted by the Horwitz curve for TCA, MC, and TSS were arranged in a manner identical to the values obtained experimentally (Table 1). Nevertheless, it should be noted that the experimental values were
RM. For this reason, it was decided to use the paired t-test. The use of this type of test is recommended when the experimental conditions are similar to those found in the present study, i.e., when the aim is to compare two different methods by means of individual measurements (using each of the methods to measure each sample) of different samples (Harris, 2010). This type of test is used when an association between repetitions of treatments is expected. The results of the statistical comparison indicated that none of the methods assessed showed significant differences for MC and TSS ( $>>0.05)$ (Table 2).

The difference between the results of SM and the RM for TCA was observed. These results demonstrated that the $\mathrm{CM}$ and the QM can be used to replace the RM for sampling and pumpkin pulp processing to determine the three characteristics assessed, whereas the SM is only restricted to MC and TSS.

The confidence intervals exhibited considerably narrow limits for TCA, $\mathrm{MC}$, and TSS, especially by the CM and QM. This observation allowed us to confirm the excellent accuracy and precision of these methods, because, when confidence intervals are narrow, the results will be close to each other and to the results of the RM. The confidence intervals, defined in a more understandable manner, though less accurately, correspond to the range of values in which there is $95 \%$ probability of finding the population mean (Harris, 2010). Considering that in the paired test the mean did not correspond to an individual value, but rather to the difference between each PM and the RM, the confidence intervals (Table 3 ) indicate that $95 \%$ of the results obtained with the application of each PM for a given characteristic will differ from the results obtained using the RM by a value within the limits of the confidence interval. Therefore, it is expected that, in $95 \%$ of the analyses, the TCA values obtained by the CM and the QM will not differ from the results of the QM by values greater than 14.3 and $13.5 \mu \mathrm{g} / \mathrm{g}$, respectively (limits with higher absolute value for each method).

All the PMs assessed achieved the 
goal of reducing the processing time and obtained inferior results in comparison to those of the RM (Tukey's test at 5\% probability) (Table 3 ).

The comparison between the PMs indicated that the CM and the SM did not differ statistically between them, and the two methods featured processing times which were statistically lower than that of the QM. The differences in processing times of the different methods were mostly due to the mass of the fruits collected to compose the bulk sample since it is necessary to slice larger portions of pulp when the bulk sample is greater. In addition, larger mass samples impose the need for additional steps of successive quartering, so that the size of the bulk sample is reduced to the size of the analytical sample.

Another factor to be noted is that in the RM, the QM, and the SM, whose surfaces (and also the masses) collected corresponded to $1 / 2,1 / 4$, and $1 / 16$ of the total fruit, respectively, there was a proportional growth between the surface and the mass collected and the size and weight of the fruit, so that the processing time was also related to these dimensions.

On the other hand, the surface of the fruits collected using the $\mathrm{CM}$ was approximately $15.7 \mathrm{~cm}^{2}$ (collection of 20 cylinders with $1 \mathrm{~cm}$ diameter), regardless of the size and weight of the fruits. For this reason, the processing time of the CM varied lesser than in the other methods, as can be observed by the comparison between the CVs, which was an advantage in favor of this method. Additionally, the short processing time and the smaller sample mass required by the $\mathrm{CM}$ allow the assessment of groups of fruits in the same analytical procedure, by means of obtaining samples composed of different fruits, for example, two or three fruits per plant, per retail store, etc. The Figure 2 shows the simplification of the sampling process by the cylinder method.

The cylinder method was considered the most suitable to replace the reference methodology, allowing a faster, safer sampling and with results statistically comparable to those provided by the reference methodology. Besides that, this method was also considered safer than the other analyzed methods because decrease of strength applied, associated with less processing time, impacted positively on the safety of sample processing, given that this procedure requires the use of knives in dark places.

\section{ACKNOWLEDGEMENTS}

The authors thank HarvestPlus for financial support of experiments. The authors were solely responsible for experimental design, data collection and analysis, preparation and submission of the manuscript.

\section{REFERENCES}

BHAT, MA; BHAT, A. 2013. Study on physicochemical characteristics of pumpkin blended cake. Journal of Food Processing and Technology 4: 1-4.

BARROS NETO, B; SCARMINIO, I; BRUNS, R. 2001. Quando as coisas funcionam normalmente. In: BARROS NETO, B; SCARMINIO, I; BRUNS, R (eds). Como fazer experimentos: pesquisa e desenvolvimento na ciência e na indústria. Campinas: Editora Unicamp. p.9-82.

BORGES, RME; LIMA, MAC; MELO, NF. 2019. Correlations between fruit yield and sensory and nutritional quality of pumpkin (Cucurbita moschata Duch.). Australian Journal of Crop Science 13: 1676-1682.

BRASIL. 2004. Instruções para execução dos ensaios de distinguibilidade, homogeneidade e estabilidade de cultiuvares de abóbora (Cucurbita spp.). Ministério da Agricultura, pecuária e abastecimento. Available at: $<$ http://www.agricultura.gov.br/...cultivar/.../ ab-d3bora-formul-c1 rio-28abr2004-49282. doc $>$. Accessed April 13, 2020.

CARVALHO, LMJ; GOMES, PB; GODOY, RLO; PACHECO, S; MONTE, PHF; CARVALHO, JLV; NUTTI, MR; NEVES, ACL; VIEIRA, ACRA; RAMOS, SRR. 2012. Total carotenoid content, $\beta$-carotene and $\beta$-carotene of landrace pumpkins (Cucurbita moschata Duch): a preliminary study. Food Research International 47: 337-340.

CARVALHO, LMJ; SMIDERLE, LASM; CARVALHO, JLV; CARDOSO, FSN; KOBLITZ, MGB. 2014. Assessment of carotenoids in pumpkins after different home cooking conditions. Food Science and Technology 34: 365-370.

CHAN-LEÓN,AC; ESTRELLA-MALDONADO, H; DUBÉ, P; ORTIZ, GF; ESPADAS-GIL, F; MAY, CT; PRADO, JR; DESJARDISN, Y; SANTAMARÍA, JM. 2017. The high content of $\beta$-carotene present in orange pulp fruits of Carica papaya $\mathrm{L}$. is not correlated with a high expression of the $C p L C Y-\beta 2$ gene. Food Research International 100: 45-56.
CONDURSO, C; VERZERA, A; DIMA, G; TRIPODI, G; CRINÒ, P; PARATORE, A; ROMANO, D. 2012. Effects of different rootstocks on aroma volatile compounds and carotenoid content of melon fruits. Scientia Horticulturae 184: 9-16.

HARRIS, DC. 2010. Quantitative chemical analysis. New York: WH Freeman \& Company. 750p.

HORWITZ, W; ALBERT, R. 1995. Precision in analytical measurements: Expected values and consequences in geochemical analyses. Fresenius' Journal of Analytical Chemistry 351: 507-513.

JASWIR, I; SHAHIDAN, N; OTHMAN, R; HASHIM, YZH-Y; OCTAVIANI, F; SALLEH, MNB. 2014. Effects of season and storage period on accumulation of individual carotenoids in pumpkin flesh (Cucurbita moschata). Journal of Oleo Science 63: 761-767.

LUTEROTTI, S; MARKOVIC, K; FRANKO, M; BICANIC, D; MADZGALJ, A; KLJAK, K. 2013. Comparison of spectrophotometric and HPLC methods for determination of carotenoids in foods. Food Chemistry 140: 390-397.

MILLER, JN; MILLER, JC. 2010. Statistics and chemometrics for analytical chemistry. 6 . ed. Harlow: Pearson Education Limited. 297p.

MORAWICKI, RO. 2010. Sampling and sampling preparation. In: NIELSEN, SS. Food analysis. West Lafayette: Springer. p.69-77.

PRIORI, D; BARBIERI, RL; MISTURA, CC; VILELA, JCB. 2018. Caracterização morfológica de variedades crioulas de abóboras (Cucurbita maxima) do sul do Brasil. Food analysis 65: 337-345.

PROVESI, JG; AMANTE, ER. 2015. Carotenoids in pumpkin and impact of processing treatments and storage. In: PREEDY, V (ed). Processing and impact on active components in food. London: Elsevier Inc. p.169-202.

RAMOS, SRR; LIMA, NRS; ANJOS, JL; CARVALHO, HWL; OLIVEIRA, IR; SOBRAL, LF; CURADO, FF. 2010. Aspectos técnicos do cultivo da abóbora na região nordeste do Brasil. Aracaju: Embrapa Tabuleiros Costeiros. 36p.

RODRIGUEZ-AMAYA, DB. 2000. Some considerations in generating carotenoid data for food composition tables. Journal of Food Composition and Analyses 13: 641-647.

RODRIGUEZ-AMAYA, DB. 2001. A guide to carotenoid analysis in foods. Washington: ILSI Press. 71p.

RODRIGUEZ-AMAYA, DB. 2002. Effects of processing and storage on food carotenoids. Sigh and Life Newsletter 2: 25-35.

RODRIGUEZ-AMAYA, DB; KIMURA, M. 2004. HarvestPlus Handbook for Carotenoid Analysis. Washington: HarvestPlus. 63p.

RODRIGUEZ-AMAYA, DB; KIMURA, M; GODOY, HT; FARFAN, JA. 2008. Updated Brazilian database on food carotenoids: factors affecting carotenoid composition. Journal of Food Composition and Analyses 21: 445-463.

SAINI, RK; NILE, SH; PARK, SW. 2015. Carotenoids from fruits and vegetables: chemistry, analysis, occurrence, bioavailability 
and biological activities. Food Research International 76: 735-750.

SÁNCHEZ, T; CEBALLOS, H; DUFOUR, D; ORTIZ, D; MORANTE, N; CALLE, F; FELDE, TZ; DOMÍNGUEZ, M; DAVRIEUX, F. 2014. Prediction of carotenoids, cyanide and dry matter contents in fresh cassava root using NIRS and Hunter color techniques. Food chemistry 151: 444-451.

SIEBER, JR; EPSTEIN, M; BRUNS, R. POSSOLO, AM. 2019. A retuned Horwitz procedure for upgrading certificates of older standard reference materials. Maryland: NIST. 31p.
SPEAKMAN, RJ; SHACKLEY, MS. 2013. Silo science and portable XRF in archaeology: a response to Frahm. Journal of Archaeological Science 40: 1435-1443.

VOGEL, AI. 2000. Vogel's textbook of quantitative chemical analysis. Harlow: Prentice Hall. 806p. 